\begin{tabular}{|c|c|c|c|c|c|c|}
\hline \multirow{4}{*}{ Impact Factor: } & ISRA (India) & $=3.117$ & SIS (USA) & $=0.912$ & ICV (Poland) & $=6.630$ \\
\hline & ISI (Dubai, UAE & $=0.829$ & РИНЦ (Russia & $=0.156$ & PIF (India) & $=1.940$ \\
\hline & GIF (Australia) & $=0.564$ & ESJI (KZ) & $=8.716$ & IBI (India) & $=4.260$ \\
\hline & JIF & $=1.500$ & SJIF (Morocco & $=\mathbf{5 . 6 6 7}$ & OAJI (USA) & $=0.350$ \\
\hline
\end{tabular}

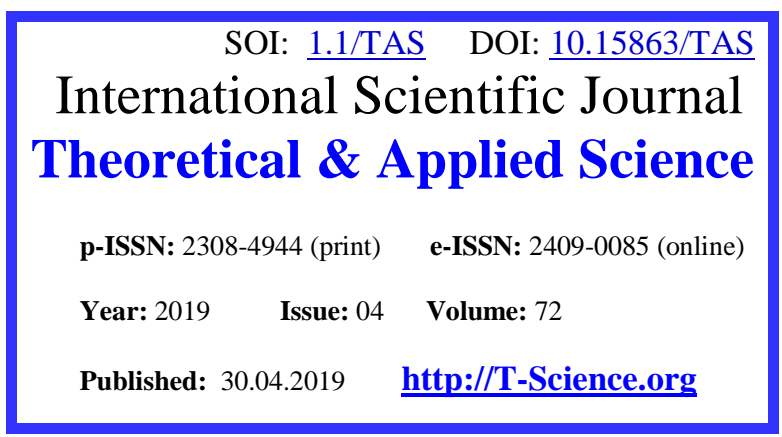

SECTION 13. Geography. History. Oceanology. Meteorology.
QR - Issue

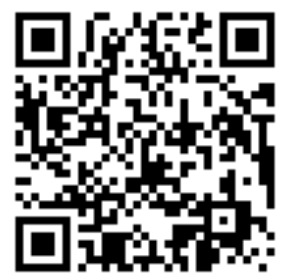

QR - Article

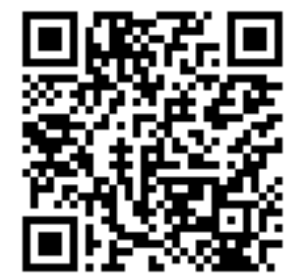

A.B. Kholikulov

PhD., Docent,

National University of Uzbekistan,

Tashkent, Republic of Uzbekistan

kholikulov@mail.ru

\title{
BUKHARA EMIRATE'S FARMING IN THE XIX-XX CENTURIES (IN THE CASE OF KASHKADARYA OASIS STABLES)
}

Abstract: This article discusses the development of land types of the Bukhara emirate in the XIX-XX centuries, as well as the development of the Kashkadarya oasis in four economic regions. It is noted that the first economic region - Shahrisabz, Kitab and Yakkabag, with its fertile lands and sufficient water supply in the emirate, is one of the largest breeding wheat, grain and barley, in the second central Kashkadarya economic region-Chirakchi.

In the Karshi economic region of the Kashkadarya region, along with the cultivation of cereals, vegetables and melons, horticulture was well developed, as well as cotton, tobacco and other crops, in the south-east Kashkadarya or Guzar economic region, the population of irrigated agriculture is due to the fact that more inadequate for its agriculture, which was the source of information of the Russian military, travelers and archival data.

Key words: Bukhara Emirate, Shahrisabz, Kitab, Yakkabag, Chirakchi, Karshi, Guzar, treasury, property title, royal lands, wheat, barley, rice, corn, cotton.

Language: English

Citation: Kholikulov, A. B. (2019). Bukhara emirate's farming in the XIX-XX centuries (in the case of Kashkadarya oasis stables). ISJ Theoretical \& Applied Science, 04 (72), 546-549.

Soi: http://s-o-i.org/1.1/TAS-04-72-73 Doi: crossef https://dx.doi.org/10.15863/TAS.2019.04.72.73

\section{Introduction}

In the 19th and early 20th centuries, as in other khanates, the Emirate of Bukhara was also the main source of wealth, and agriculture was the main source of income. As in other parts of the Emirates, arable land in the Kashkadarya Valley consists of two:irrigated landsandnaturally irrigated [1, P. 30]. All irrigated land in the emirate is divided into several types, such as: private property, titles, treasury, royal lands [2, P. 194].

Kashkadarya, which is an important source of water, supplied 600,000 of its colonies with water to Shahrisabz, Yakkabag, Chirakchi, Guzar and Karshi [3, P. 11]. The land was 79.988, Shahrisabz 48.427, Yakkabag 95.864, Chirakchi 602.983, Guzar 31.650, and Karshi - 205.005 units [4].

The rivers of the oasis of Kashkadarya had 224 irrigation canals at the end of the XIX century. The length of these channels is $25 \mathrm{~km}$, the rest - 4-8 km. The Kashkadarya basin can be divided into two parts: water supply (Shahrisabz) and lower water (Karshi), which lacks water. In the upper part of the river, the swamps were caused by an abundance of water, and the lower part often dried out [5, P. 40.].

\section{Materials and methods}

At the beginning of the XIX-XX centuries, the oasis agriculture developed in four economic areas:

1. East Kashkadarya - plains and mountainous areas of Shahrisabz, Kitab and Yakkabag regions.

2. Area of middle Kashkadarya or Chirakchi.

3. Lands of the south-east of Kashkadarya or Guzar regions.

4. Karshi land in the lower reaches of Kashkadarya.

In the case of agriculture, we consider the development of agriculture on the example of the four economic regions above.

The first economic region - Shahrisabz, Kitab and Yakkabag differed in the emirate with their fertile land and sufficient water supply. Most of the population was engaged in farming [6, P. 176]. Grain growing is a major place in agriculture. Mahmud Ibn Walid claims that in Shahrisabz a good harvest is obtained from grain [7, P. 76]. On the land of Shahrisabz, wheat, barley, oats and planted with herbs [8, P.85-86]. In the area Yakkabag were large wheat pellets. Lands have a good grain harvest.

The fields of Shahrisabz mainly consist of wheat, barley, four types of rice, corn, cotton, sesame, sage, 


\begin{tabular}{|c|c|c|c|c|c|c|}
\hline \multirow{4}{*}{ Impact Factor: } & ISRA (India) & $=3.117$ & SIS (USA) & $=0.912$ & ICV (Poland) & $=6.630$ \\
\hline & ISI (Dubai, UAE & $=0.829$ & РИНЦ (Russia & $=0.156$ & PIF (India) & $=1.940$ \\
\hline & GIF (Australia) & $=0.564$ & ESJI (KZ) & $=8.716$ & IBI (India) & $=4.260$ \\
\hline & JIF & $=1.500$ & SJIF (Morocco & $=5.667$ & OAJI (USA) & $=0.350$ \\
\hline
\end{tabular}

flax, lentils, beans, tobacco seeds (poppy and safflower), greens, onions, beets, cinnamon, cabbage, cucumber, (long cucumber), turnip, pepper, carrot, melon and watermelon. They are from the beginning of spring, from March 15th to April 15th; winter wheat and barley are planted from the beginning of the criterion. Rice of grain crops is grown in large quantities, according to the emirs of Bobobek and Jurabek, the breeding stations of Kitab and Shahrisabz were sown with wheat and barley for $3 / 10$ of the sown area and rice for $4 / 10$ of the rice and the remaining $3 / 10$ of other crops. Depending on the time of planting, the above-mentioned crops are divided into two types: white (wheat, barley, lentil, linseed, and pea) and blue (those that fall into it). When the crop is harvested twice a year and the white crop is harvested, green crops are planted.

Shahrisabz gardens include orchards, vineyards and grapes of the same species, the second type is mixed fruit trees, and the third type is trees of ornamental trees used for building the jungle.

In the gardens of Shahrisabz, fruit trees are planted, such as apples, apricot, grapes, peach, pomegranate, almond, quince, walnut, plum, cherry. In Russian sources, it is noted that the Kitab district was covered with green gardens [9], and peaches were popular in the Bukhara emirate [10, P. 475]. Tree species used in construction include poplars and ribs [11, P. 19-21]. Most mulberry trees created the basis for silk development. According to data of the 19th century, "Shahrisabz" and adjacent cotton were popular, and "the cotton brought to Bukhara from Russia was mainly obtained from Sarsabz (Shahrisabz)" [12, P. 49].

Tobacco was also grown in Eastern Kashkadaryaand contained up to 1,050 cows per year in oak stables, written in archival documents [13]. As a result, high yields and large water resources, most of the agricultural commodities, produced in the economic regions of Shahrisabz, Kitab and Yakkabag, most of the products were exported to other cities.

Wheat and barley are grown in the economic region of middleKashkadarya, especially in Chirakchi region. The region is one of the largest grain producing regions. Karakalpak farm is famous for its own crops, it could afford to grow 2,000 bats of wheat and 1,000 barley per year $[14$, P. 325]. In Beshchashma area, from a few wheat flour at a rate of 60 pounds. Mainly, melon seeds, beets, carrots, turnips, cauliflower, onions, cucumbers, peas, lentils, beans, watermelons, melons, zucchini are planted in the district. Grapes, pomegranates, figs, peaches, apricots, apples, pears, quinces, cherries, almonds and oleasterwere grown. Among the fruit trees, apricots, pomegranates, are the most productive, their dried fruits were delivered to local needs, as well aswere exported to Russia [15, P. 124].

Vegetable growing and horticulture are developed on irrigated fertile soils in the Kashkadarya
River. Sources include livestock vines, onions, carrots and cotton fields[16, P. 104]. The fertile land of the Chirakchihad sufficient amount of water from Kashkadarya. Peasantsfrom Karshi and Samarkand came here and rented land and planted crops.

The village of Nekuz, about $12 \mathrm{~km}$ away from Karshi, the land was watered by Chitarik and belongs to Karshi madrasah. The main crops are wheat and barley, and cotton was planted at the beginning of the 20th century.

Horticulture is well developed in the Karshi economic region, located in the foothills of the Kashkadarya, along with the cultivation of cereals, vegetables and melons. Cotton, tobacco and other crops are also grown. According to the historical data, the Karshi region's spring is green, grains and sweet melons are grown, hasn't enough water source[17, P. 47],can harvest adequate yields under favorable weather conditions, hasn't yields in drought period [18, P. 188-191].

Mir Izzatullah, who lived in Kosa and Karshi in 1813, written that wheat and barley were grown, caravans stopped in Karshi for 3-4 days for providing water, barley and nutrients for travel [19, P. 213].

During this period, Karshi had plenty of water merely in spring. In June, July and August, water was delivered to Karshievery 10 days a month from Shahrisabz, Kitab and Guzar in turn. Water couldn't reachto its destination cause ofhot air, was dried on the road and watered only the gardens of Karshi. Nevertheless, because of the productive land, the yield of wheat reached 500,000 batman. Half of the land in Beclak belongs to the land, and the rest is injured. White and blue tobacco varieties were planted [10, P. 468], and the best tobacco producers are grown by residents of Karshi [20]. The popularity of tobacco products, like pomegranates and grapes of Shahrisabz, is mentioned in many sources.

Karshi district is also famous for its gardens and vineyards. In Karshi, Chirakchi, Husar there are large vineyards, as well as grapes, a mask, white raisins and nutmeg. The population of the vineyard had of myriad benefit, Karshi grapes and raisins are very popular not only in Central Asia, but also beyond its borders [21, P. 10]. The absence of gardening in the garden of the Zarafshan oasis is reflected in sources and archival documents [22, P. 92]. The surroundings of Karshi are surrounded by melons, gardens and vineyards. Izzatullah declares: "The gardens around Karshi are well-known for their wonderful grapes and vines [23, P. 213]. The beautiful gardens of the city were also mentioned by A. Bornes [24, P. 374].

Silkworm breedingwas also common in Karshidistrict [25]. Varieties of confectionery and jam are made from juice fromtaranjabinflower in the desert surrounding Karshi [26, P. 168-169].

Koson was also famous for its horticulture and all incomes from the gardens was directly transferred to the treasury of Karshi. [27, P. 55] 


\begin{tabular}{|c|c|c|c|c|c|c|}
\hline \multirow{4}{*}{ Impact Factor: } & ISRA (India) & $=3.117$ & SIS (USA) & $=0.912$ & ICV (Poland) & $=6.630$ \\
\hline & ISI (Dubai, UAE & $=0.829$ & РИНЦ (Russia & $=\mathbf{0 . 1 5 6}$ & PIF (India) & $=1.940$ \\
\hline & GIF (Australia) & $=0.564$ & ESJI (KZ) & $=8.716$ & IBI (India) & $=4.260$ \\
\hline & JIF & $=1.500$ & SJIF (Morocco & $=5.667$ & OAJI (USA) & $=0.350$ \\
\hline
\end{tabular}

At the beginning of the 20th century, cotton production in Karshi developed significantly [28, P. 341]. According to the data in 1913, there are 317,600 hectares of land in the oasis, of which 2,000 hectares was used to plant cotton. In 1913, the yield was 5 centners per hectare, and cotton, 7.3 centners per hectare.

The population of the southeastern Kashkadarya or Guzar economic region had more agriculture due to the lack of water resources for irrigated agriculture. Drinking water is mainly extracted from wells.

Dwellers who deal with farming grew wheat and barley on $3 / 4$ of their land [29, P. 166]. Rice, as well as cotton, carrots and low-fat cornerswere sown the rest of the land. These crops are mainly planted in the northwestern part of the Guzar valley. Wheat and barley are harvested from 10 to 20 tonnes, which gives an average annual yield of 165,000 tonnes.

There were few gardens in Guzara and in its northwest, but gardening is limited only witholeaster in the big and small Urariver, fruit trees are not planted in the Kirschakdarya valley.

Apricot, peach, cherry, apple, pear, quince, almond, pomegranates and grapes are grown in beklik land. Grapes, especially the maska varieties and apricot are famous for their unrepeated taste. Dried apricots and raisinsexported to Bukhara and Russian. Fiber, poplar, elm, and mulberry were used for building materials, wood, and other needs.

Wheat grains in this area are divided into three types: white wheat, red wheat and black wheat. Up to $100-150$ pounds of barley could be harvested on each10 square meters of irrigated land.
There are two types of millet: white and red varieties, and each tithe is collected from 80 to 100 pounds. Usually, in early June, the sowing of winter wheat or barley was harvested, as well as in September and October. If planted separately, it is planted in April and collected in July or early August. Nearly $150-180$ pounds of peanuts and about $80-120$ pounds of corn were harvested. [10, P. 442-450].

Lessar, a political agent in Bukhara in the 80's of the 19th century, studied the state of the irrigation system and developed a project to developlarge part of the beklik land and Karshi desert through using Amudarya water. However, 7 millionrubleshad to be allocated for this project from emirates treasure. Bukhara's government couldn't afford such huge cost, afterwards the project was not implemented. However, without the construction of large irrigation systems, it was concluded that with the help of existing canals in the Kashkadarya Valley, more than 2000 square meters area could be used [16, P. 88-89].

\section{Conclusion}

In summary, in the XIX-XX centuries, agriculture and livestock were the basis of economic life in Kashkadarya oasis. Mountainous and foothill areas of the region were specializing in livestock, agriculture and gardening, steppes was specializing in nomadic livestock farming, and riverside areas were specializing in settled agriculture.

In the XIX-XX centuries, traditional forms and types of cultivation of agriculture were preservedin the Kashkadarya region, manufacturing was associated with the requirements of the domestic and foreign markets.

\section{References:}

1. Kun, A. A. (1880). Ocherki Shagrisebzskogo bekstva. ZIRGO po otdeleniyu etnografii. SPb., T.VI.

2. Geyer, I. I. (1909). Turkestan. Tashkent.

3. Logofet, D. I. (1911). Buxarskoe xanstvo pod russkim protektoratom. SPb.: B.I., T. II. pp. 78.

4. Remez, I. A. (1922). Vneshnyaya torgovlya Buxari do mirovoy voyni. Tashkent: SSU Turkrespubliki.

5. Astanova, G. Y. (1990). Dokumentalnie istochniki Buxarskogo xanstva XIX nachala XX v. ob administrativnix deleniyax $i$ ix razmerax. Pozdnefeodalny gorod Sredney Azii. Aktualne problem istoricheskoy nauki. (p.218). Tashkent: Fan. O'zR MDA. 51-jamg'arma, 1-ro'yxat, 102 ish, 1-2 varaq.
6. (1926). Material po rayonirovaniyu Sredney Azii. Territoriya i naselenie Buxari i Xorezma. Buxara - Tashkent. Kn. I. Ch.1.

7. Arxipov, K. (1884). Voennaya rekognossirovka ravninnoy chasti Buxarskogo xanstva, proizvedennaya $v \quad 1883 \quad g$. Sbornik geograficheskix, topograficheskix i statisticheskix materialov po Azii. SPb.: Voennaya tipografiya. Vp. XX.

8. Makhmud ibn Vali. (1970). Bakhr-al asror fi manakib al-khayr (More tayn otnositelno doblestey blagorodnix). Geografiya / Perevod, vvedenie, primechaniya i ukazateli B.A.Axmedova. Tashkent: Fan.

9. Bekchurin (1873). Shakhrisabzkoe vladeniya po rasskazam Djurabeka i Bababeka. Turkestanskiy sbornik. SPb., T. 60. 


\begin{tabular}{|c|c|c|c|c|c|c|}
\hline \multirow{4}{*}{ Impact Factor: } & ISRA (India) & $=3.117$ & SIS (USA) & $=0.912$ & ICV (Poland) & $=6.630$ \\
\hline & ISI (Dubai, UAE & $=0.829$ & РИНЦ (Russia & $=0.156$ & PIF (India) & $=1.940$ \\
\hline & GIF (Australia) & $=0.564$ & ESJI (KZ) & $=8.716$ & IBI (India) & $=4.260$ \\
\hline & JIF & $=1.500$ & SJIF (Morocco & $=5.667$ & OAJI (USA) & $=0.350$ \\
\hline
\end{tabular}

10. Logofet, D. (1907). Cherez Buxaru. Putevie ocherki po Sredney Azii. Turkestanskiy sbornik. Tashkent. T. 443. p.38a.; Voenny sbornik. №2. p. 215.

11. Semyonov-Tyan-Shanskiy, V. P. (1913). Rossiya. Polnoe geograficheskoe opisanie. Turkestanskiy kray. SPb.: Izd-vo A.F.Devriena. T. XIX.

12. Kun, A. A. (1880). Ocherki Shagrisebzskogo bekstva. ZIRGO po otdeleniyu etnografii. SPb. T.VI.

13. Agzamova, G. A. (2002). Shahrisabz-iqtisodiy va madaniy hayot markazi (XVI - XIX asrning birinchi yarmi). Shahrisabz shahrining jahon tarixida tutgan o'rni. Xalqaro ilmiy konferensiya ma'ruzalari tezislari. Toshkent: Fan.

14. (n.d.). O`zR MDA. 126-jamg'arma, 1-ro‘yxat, 621-ish, 1-varaq.

15. Maev, N. (1879). Ocherki gornix bekstv. Material dlya statistiki Turkestanskogo kraya. SPb. Vp.V.

16. (1888). Polk. yevreynov. Rekognossirovka puti cherez Djamskiy pereval na Guzar i na Karshi v 1887 g. // Sbornik geograficheskix, topograficheskix i statisticheskix materialov po Azii. SPb.: Voennaya tipografiya. Vp. XXXVI.

17. Logofet, D. I. (1911). Buxarskoe xanstvo pod russkim protektoratom. $\mathrm{SPb}$.: B.I. T. II.

18. Zahiriddin, M. B. (1989). Boburnoma / Nashrga tayyorlovchi P. Shamsiev. Toshkent: Yulduzcha.

19. Termiziy, X. S. (1997). Dastur ul-Muluk/Forstojik tilidan erkin tarjima, so 'zboshi, izohlar muallifi J. Esonov. Toshkent: Adabiyot va san'at.

20. Sokolov, V. Y. (1957). Buxara, Samarkand, Kelif v 1813 godu. Publikatsiya iz otrvka «Puteshestvie Mir Izzat Ull v Srednyuyu Aziyu v
1812-1813» // Trud SAGU. Vp. X. Tashkent: SAGU.

21. Meyendorf, E. K. (1886). Svedeniya o Buxare // Turkestanskiy sbornik. (p.169a). SPb. T. 385.

22. (1983). Zapiski o Buxarskom xanstve. Otchet P.I.Demezona i I.V.Vitkevicha. Moscow: Nauka.

23. (1959). Kashkadarinskaya oblast. Ekonomikogeograficheskaya xarakteristika. Tr. SAGU. Tashkent: SAGU. T.II. Vp. 156.

24. Litvinov, B. N. (1910). Karshi // Turkestanskiy sbornik. Tashkent, 1910-1911. T. 542.

25. Sokolov, Y. A. (1957). Buxara, Samarkand, Kelif v 1813 godu. Publikatsii otrovka iz "Puteshestvie Mir Izzat Ull v Srednyuyu Aziyu v 1812-1813 godax" Trud SAGU. Tashkent: Vp. X.

26. Borns, A. (n.d.). Puteshestvie v Buxaru. Turkestanskiy sbornik. SPb., T. 38.

27. (n.d.). O`zR MDA. 1-jamg'arma, 34-ro'yxat, 172-ish, 27 orqa, 35-varaqlar.

28. Meyendorf, E. K. (n.d.). Svedeniya o Buxare. Turkestanskie sbornik. T. 385.

29. Maev, N. A. (1875). Ocherki Buxarskogo xanstva. Tashkent.

30. Kostenko, L. F. (1871). Puteshestvie v Buxaru russkoy missii v 1870 godu. S marshrutom ot Tashkenta do Buxari. Turkestanskiy sbornik. SPb. T. 32.

31. (1894). Polk. Fedorov. Statisticheskiy ocherk Guzarskogo $i$ Kuytangskogo $i$ Kallyukskogo amlyakdarstv Kelifskogo bekstva. Sbornik geograficheskix, topograficheskix i statisticheskix materialov po Azii. SPb.: Voennaya tipografiya. Vp. LVII. 